\title{
Tutupan Terumbu Karang di Perairan Pulau Larearea Kabupaten Sinjai Sulawesi Selatan
}

\author{
Coral Reef Coverage in Larearea Island \\ Sinjai District South Sulawesi
}

\author{
Ridha Alamsyah', Armita Permatasari ${ }^{2}$, Irfan Fauzi ${ }^{3}$ \\ ${ }^{1-3}$ Sekolah Tinggi Ilmu Pertanian Muhammadiyah Sinjai \\ E-mail : alamsyahridha@gmail.com
}

\begin{abstract}
Abstrak
Kondisi terumbu karang di Indonesia terus mengalami tekanan akibat aktivitas manusia dan pemanasan global. Penelitian ini bertujuan untuk mengetahui tutupan karang diperairan Pulau Larearea yang akan menjadi dasar dalam kebijakan pengelolaan dan konservasi ekosistem terumbu karang di Kabupaten Sinjai. Pengukuran dilakukan setiap stasiun pengamatan menggunakan metode garis transek (Line Intercept Transect). Standarisasi pengkategorian kondisi terumbu karang mengacu pada Keputusan Menteri Negara Lingkungan Hidup No. 04/MENLH/02/2001 tentang Kriteria baku Kerusakan Terumbu Karang. Hasil yang diperoleh, Tutupan karang diperairan Pulau Larearea termasuk dalam kategori rusak dan sedang. Karang hidup didominasi oleh tipe pertumbuhan massif dan bercabang, sedangkan karang mati didominasi oleh karang mati yang telah ditumbuhi alga.
\end{abstract}

Kata kunci : Tutupan; Karang; Pulau Larearea

\begin{abstract}
The condition of coral reefs in Indonesia continues to experience pressure due to human activities and global warming. This study aims to determine the coral coverage in the waters of Larearea Island which will be the basis in the management and conservation of coral reef ecosystems in Sinjai Regency. Measurements were made at each observation station using the Line Intercept Transect method. Standardization of categorizing coral reef conditions refers to the Decree of the Minister of Environment No. 04/ MENLH / 02/2001 concerning the standard criteria for Coral Damage. The results obtained, coral cover in the waters of Larearea Island are included in the broken to moderat category. Live corals are dominated by massive and branched growth types, while dead corals are dominated by dead coral with algae.
\end{abstract}

Keywords: Coverage; coral; Larearea Island 


\section{PENDAHULUAN}

Pulau Larearea merupakan bagian dari gugusan pulau di Kepulauan Sembilan Kabupaten Sinjai Sulawesi Selatan. Karakteristik kepulauan sembilan seperti halnya dengan pulau-pulau kecil lainnya di Indonesia yakni terdiri dari daratan dan perairan yang menyimpan begitu banyak potensi. Salah satu potensinya adalah ekosistem terumbu karang dengan tingkat produktivitas tinggi. Kondisi terumbu karang perairan Pulau Larearea berdasarkan analisis penginderaan jauh terdiri dari 47,54\% dalam keadaan hidup dan 35,19\% mati, 17,27\% pasir (Alamsyah dkk., 2019).

Peranan terumbu karang sangat besar dalam sistem perairan, namun sangat rentan terhadap pengaruh dan tekanan perubahan lingkungan baik yang ditimbulkan oleh aktivitas manusia maupun dampak dari perubahan iklim secara global. Kerusakan ekosistem disebabkan karena aktivitas dari daratan seperti limbah rumah tangga, aktivitas pendaratan kapal yang tidak ramah lingkungan, dan prilaku pemanfaatan ekosistem yang tidak ramah lingkungan. Fungsi dan manfaat alami terumbu karang yaitu (a) Melindungi pantai dari hempasan ombak; (b) sebagai tempat tinggal, berlindung, mencari makan, dan memijah ikan dan biota laut, sumber pangan dan obat- obatan; (c) penunjang kegiatan pendidikan dan penelitian; (d) sebagai tempat wisata (Hadi dkk., 2018).

Ekosistem terumbu karang merupakan ekosistem pesisir yang didalamnya terkandung sumber daya alam penting dan bermanfaat bagi manusia. Keberadaan ekosistem terumbu karang dengan tingkat keanekaragaman yang tinggi merupakan potensi besar yang harus dijaga kelestariannya. Keanekaragaman karang Indonesia terdiri dari Scleractinia (karang batu) sebanyak 569 jenis, non sclerectinia 8 jenis Octocoralia (karang lunak) 311 jenis dan Gorgonia (karang kipas) sebanyak 271 jenis (Suharsono, 2014). Studi dan pengamatan terhadap terumbu karang diperairan Pulau Sembilan telah dilakukan oleh Suharyanto \& Utojo (2005) dan didapatkan kondisi terumbu karang pada kriteria sedang sampai dengan baik. Karang didominasi oleh Acropora bercabang, karang bercabang non acropora, karang daun dan karang massif. 
Populasi penduduk yang semakin meningkat dengan kemajuan teknologi, mengakibatkan terjadinya eksploitasi karang yang cenderung tidak terkendali. Pemanfaatan sumber daya yang bersifat eksploitatif dan tidak memperhatikan daya dukung lingkungan, tentunya akan berdampak negatif terhadap kelestarian terumbu karang bagi generasi mendatang. Pengambilan material untuk bahan bangunan menyebabkan penurunan fungsi perlindungan alami terhadap erosi pantai dan rusaknya ekosistem, menurunya pendapatan nelayan, berkurangnya nilai estetika pantai, dan penurunan kualitas perairan (La Sara, 2014).

Sampai saat ini kondisi terumbu karang tidak hanya di Pulau Larearea, tetapi umumnya di Kabupaten Sinjai belum menjadi perhatian penting. Sementara tingkat kerusakan semakin parah dan aktivitas manusia pada ekosistem terumbu karang semakin tak terkendali. Oleh karena itu penelitian tentang kondisi tutupan terumbu karang menjadi sangat penting untuk mengetahui kondisi ril dan tingkat kesehatan ekosistem di perairan Pulau Larearea. Data dan informasi tutupan karang akan menjadi dasar dalam kebijakan pengelolaan dan konservasi ekosistem terumbu karang di Kabupaten Sinjai. Inventarisasi karakteristik karang di lokasi, kondisi terkini, dan keanekaragaman biota yang ada dalam ekosistem tersebut. Data akurat potensi karang akan mendukung program pemerintah terkait konservasi dan rehabilitasi ekosistem pesisir dan laut sebagai bidang fokus riset kemaritiman. Untuk dapat mengelola suatu kawasan terumbu karang secara baik dan benar harus mengetahui betul-betul kondisi dan kesehatan ekosistem yang ada, sumber daya alam apa saja yang dapat dimanfaatkan dan bagaimana kondisinya (Madduppa dkk., 2017)

\section{METODE PENELITIAN}

Waktu dan Tempat

Penelitian ini dilaksanakan pada Bulan Februari-Juni Tahun 2019 di Pulau Larearea Kecamatan Sinjai Utara, Kabupaten Sinjai Provinsi Sulawesi Selatan.

\section{Prosedur Penelitian}

Pengamatan tutupan terumbu karang perairan Pulau Larearea dilakukan pada enam stasiun yakni utara ( $5^{\circ} 4^{\prime} 4,72$ ” LS dan $120^{\circ} 23^{\prime} 34,55^{\prime}$ BT), timur 
(5 4' 15,54" LS dan $\left.120^{\circ} 23^{\prime} 35,21^{\prime \prime} \mathrm{BT}\right)$, tenggara (5'4' 21,60" LS dan $120^{\circ} 23^{\prime}$ $34,85^{\prime \prime}$ BT), selatan ( $5^{\circ} 4^{\prime} 25,39^{\prime \prime} \mathrm{LS}$ dan $\left.120^{\circ} 23^{\prime} 35,55^{\prime \prime} \mathrm{BT}\right)$, barat daya $\left(5^{\circ} 4^{\prime}\right.$ 23,26” LS dan $\left.120^{\circ} 23^{\prime} 22,37^{\prime \prime} \mathrm{BT}\right)$, serta barat laut (5 $5^{\circ} 4^{\prime} 12,46^{\prime \prime} \mathrm{LS}$ dan $120^{\circ}$ 23 '24,41" BT). Sebelah timur laut dan barat tidak dilakukan pengamatan sebab wilayah ini didominasi oleh lamun dan pasir.

Pengukuran terumbu karang pada setiap stasiun menggunakan metode garis transek (Line Intercept Transect) pada kedalaman 3-5 meter untuk masingmasing stasiun dengan pertimbangan bahwa sebaran karang lebih banyak dijumpai pada kedalaman tersebut. Pengamatan dilakukan dengan meletakkan meteran sepanjang $50 \mathrm{~m}$ sejajar garis pantai dengan posisi pantai ada disebelah kiri pengamat (Manuputty \& Djuwariah, 2009). Pencatatan karang selanjutnya dilakukan saat berada tepat digaris meteran dengan ketelitian hingga $\mathrm{cm}$. Satu koloni dianggap satu individu. Jika dalam satu koloni dari jenis yang sama dipisahkan oleh satu atau beberapa bagian yang mati, tiap bagian yang hidup dianggap sebagai satu individu tersendiri. Apabila dua koloni atau lebih tumbuh diatas koloni yang lain, tiap koloni tetap dihitung sebagai koloni yang terpisah. Data hasil pengamatan kemudian dianalisis untuk mendapatkan besaran persentase tutupan karang.

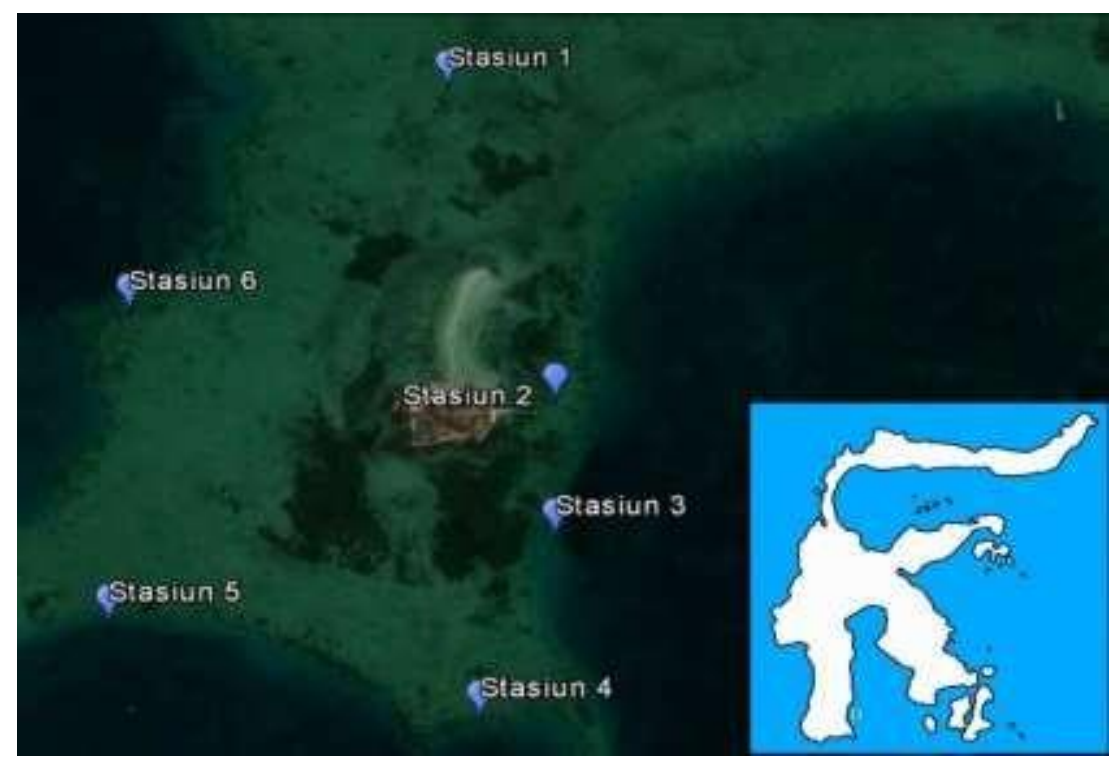

Gambar 1. Lokasi pengamatan karang di perairan Pulau Larearea

$$
\text { Persentase penutupan }=\frac{\text { Total panjang kategori }(L)}{\text { Panjang transek }(Y)} \times 100 \%
$$


Standarisasi pengkategorian kondisi terumbu karang mengacu pada Keputusan Menteri Negara Lingkungan Hidup No. 04/MENLH/02/2001 tentang Kriteria baku Kerusakan Terumbu Karang yang dibagi menjadi 4 (empat) kategori : Rusak (0-24,9\%), Sedang (25-49,9\%), Baik (50-74,9\%), dan Baik Sekali (75-100\%) (Menteri Negara Lingkungan Hidup, 2001).

\section{HASIL DAN PEMBAHASAN}

Tutupan karang yang menjadi indikasi dalam menentukan kondisi kesehatan terumbu karang dapat diketahui dengan mengamati lifeform dan persentase tutupannya (Tabel 1). Pada semua stasiun penelitian persentase karang hidup lebih rendah dibandingkan dengan karang mati. Karang hidup terdiri dari karang keras dan karang lunak, sedangkan karang mati terdiri dari karang mati dan yang ditumbuhi alga, pecahan karang dan non karang (pasir).

Berdasarfan lifeform atau pola pertumbuhan karang, maka jumlah tertinggi diperoleh pada karang massif (massive). Ditemkukan pada semua stasiun dengan persentase yang cukup tinggi. Frekuensi karang massif yang tinggi salah satu penyebabnya adalah karena lebih tahan terhadap tekanan lingkungan dibandingkan dengan karang lainnya, Beberapa telah mengalami kematian dan menjadi pecahan karang. Bentuk pertumbuhan karang yang massif mampu bertahan hidup pada kondisi arus yang cukup tinggi (Zamani, 2015).

Tabel 1. Persentase tutupan lifeform karang di perairan Pulau Larearea

\begin{tabular}{|c|c|c|c|c|c|c|c|}
\hline \multirow{2}{*}{ No } & \multirow{2}{*}{ Lifeform } & \multicolumn{6}{|c|}{ Persen Tutupan per Stasiun (\%) } \\
\hline & & 1 & 2 & 3 & 4 & 5 & 6 \\
\hline 1 & Coral Branching & 14,38 & 0,66 & 19,92 & 5,62 & 6,18 & 10,72 \\
\hline 2 & Coral Encrusting & & & & 4,04 & & \\
\hline 3 & Coral Foliose & & 0,42 & & & 2,04 & \\
\hline 4 & Coral Massive & 7,58 & 8,74 & 5,2 & 32,74 & 19,8 & 10,62 \\
\hline 5 & Coral Submassive & & & & 4,44 & 4,86 & \\
\hline 6 & Coral Soliter & & & & & 0,48 & 0,1 \\
\hline 7 & Soft Coral & 4,28 & & & 1,2 & & \\
\hline 8 & Dead Coral & 11,14 & 1,7 & & 8,46 & 2,1 & 0,1 \\
\hline 9 & Dead Coral with Algae & 14,96 & 13,74 & 22,7 & 23,52 & 17,9 & 26,22 \\
\hline 10 & Rubble & 2,82 & 14,42 & 23,3 & & 2,42 & 7,36 \\
\hline 11 & Sand & 44,84 & 60,32 & 28,88 & 19,98 & 44,22 & 44,88 \\
\hline
\end{tabular}




\begin{tabular}{ccccl}
\hline No & Titik Koordinat & Stasiun & $\begin{array}{c}\text { Persen } \\
\text { Tutupan } \\
\text { Karang Hidup } \\
(\boldsymbol{\%})\end{array}$ & Kategori \\
\hline 1 & $5^{\circ} 4^{\prime} 05,67^{\prime \prime} \mathrm{LS}$ dan $120^{\circ} 23^{\prime} 32,36^{\prime \prime} \mathrm{BT}$ & Stasiun 1 & 26,24 & Sedang \\
2 & $5^{\circ} 4^{\prime} 16,21^{\prime \prime} \mathrm{LS}$ dan $120^{\circ} 23^{\prime} 35,31^{\prime \prime} \mathrm{BT}$ & Stasiun 2 & 9,82 & Rusak \\
3 & $5^{\circ} 4^{\prime} 20,56^{\prime \prime} \mathrm{LS}$ dan $120^{\circ} 23^{\prime} 35,18^{\prime \prime} \mathrm{BT}$ & Stasiun 3 & 25,12 & Sedang \\
4 & $5^{\circ} 4^{\prime} 26,24^{\prime \prime} \mathrm{LS}$ dan $120^{\circ} 23^{\prime} 32,89^{\prime \prime} \mathrm{BT}$ & Stasiun 4 & 48,04 & Sedang \\
5 & $5^{\circ} 4^{\prime} 23,26^{\prime \prime} \mathrm{LS}$ dan $120^{\circ} 23^{\prime} 22,37^{\prime \prime} \mathrm{BT}$ & Stasiun 5 & 33,36 & Sedang \\
6 & $5^{\circ} 4^{\prime} 13,23^{\prime \prime} \mathrm{LS}$ dan $120^{\circ} 23^{\prime} 22,86^{\prime \prime} \mathrm{BT}$ & Stasiun 6 & 21,44 & Rusak \\
\hline
\end{tabular}

Tutupan karang dengan persentase hidup tertinggi diperoleh pada stasiun 4 yakni 48,04\%. Tingginya tutupan tersebut karena wilayah ini terletak disebelah selatan pulau yang tidak banyak mendapatkan pengaruh dari aktivitas antropogenik termasuk kegiatan penangkapan ikan. Menurut Lutfhi, dkk (2019) penurunan luasan terumbu karang lebih banyak disebabkan oleh faktor antropogenik dibandingkan yang lain. Selain itu lokasi sebelah selatan pulau juga merupakan area terbuka sehingga pertukaran air melalui arus dapat berjalan dengan baik. Pola arus yang mengalir secara terus-menerus menjamin tersedianya makanan bagi hewan karang, air yang jernih, substrat dasar keras dan lekuk-lekuk pantai yang dalam serta sedikitnya sedimentasi yang dibawa oleh sungai merupakan jaminan bagi pertumbuhan karang yang ideal (Zamani, 2015).

Tutupan karang hidup dengan persentase terendah didapatkan pada stasiun 2. Kondisi ini disebabkan karena wilayah tersebut sangat dekat dengan dermaga sehingga kerusakan lebih banyak disebabkan oleh pembuangan jangkar pada saat kapal berlabuh. Hal ini terlihat dari persentase karang mati dan pecahan karang yang cukup tinggi yakni 29,86\%. Kondisi ini juga berdampak pada stasiun 3 yangjaraknya cukup dekat dengan stasiun 2, dimana persentase karang mati mencapai $46 \%$.

Pulau Larearea saat ini menjadi salah satu daerah wisata di Kabupaten Sinjai sehingga diduga kegiatan pariwisata juga mempengaruhi persentase karang mati. Persentase tutupan karang sangat dipengaruhi oleh tekanan dari lingkungan disekitarnya termasuk tekanan pariwisata (Farid dkk, 2018)

Secara umum tutupan karang diperairan Pulau Larearea dalam kondisi rusak $(9,82 \%)$ sampai dengan sedang (48,04\%), tidak ditemukan kondisi baik atau baik sekali. Dari enam stasiun pengamatan empat diantaranya masuk 
kategori sedang yakni stasiun 1, 3, 4 dan 5. Stasiun 2 dan 6 masuk dalam kategori buruk. Kondisi yang sama di perairan pantai Ulee Kabupaten Bireuen Aceh persentase tutupan karang rata-rata 23,92\% dan masuk pada kategori sedang (Zewanto dkk, 2017). Begitu pula di perairan Gili Tangkong Lombok Barat juga masuk dalam kategori sedang meskipun tutupan karang yang didapatkan sebesar 46\% (Candri dkk, 2019). Perairan pulau karimunjawa juga dalam kondisi sedang yakni berkisar antara 25-49,9\% (Yusuf, 2013) Sedangkan di perairan Liukang Tangaya Kabupaten Pangkep sangat memprihatinkan karena kondisi tutupan karang hanya 18,91\% dan masuk dalam kaetogi buruk (Nurhidayat dkk, 2019). Jika keadaan seperti ini terus berlangsung tanpa ada upaya perbaikan maka kondisi terumbu karang diperkirakan akan semakin buruk. Terdapat dua penyebab utama kerusakan yakni karena faktor alam seperti pemanasan global yang terus meningkat, kedua karena faktor antropogenik seperti pengasaman laut, overfishing, polusi, dan kegiatan pariwisata yang tidak terkontrol.

Informasi kondisi tutupan terumbu karang menjadi dasar pertimbangan bagi penentu kebijakan dalam menyusun model pengelolaan yang tepat. Manajemen terumbu karang berbeda antara satu lokasi dengan lokasi yang lain disebabkan karena perbedaan karakter ekobiologi dan masyarakat sebagai kontributor terbesar yang mempengaruhi kondisi terumbu karang disetiap lokasi. Keadaan demikian menjadi informasi tentang perlunya rehabilitasi terhadap ekosistem terumbu karang. Menurut Kusumo dkk (2019) pemulihan ekosistem karang dapat dilakukan dengan menggunakan indikator ekologi, sosial dan ekonomi. Ekosistem karang yang baik dapat menunjang keanekaragaman biota yang ada di ekosistem tersebut dan akan bermanfaat bagi kehidupan manusia. Tingginya tutupan karang mendukung keanekaragaman spesies (Arisandi dkk, 2018)

\section{KESIMPULAN}

Tutupan karang diperairan Pulau Larearea termasuk dalam kategori rusak sampai dengan sedang dengan persentase tutupan 9,82\% sampai dengan sedang 48,04\%. Karang hidup didominasi oleh tipe pertumbuhan massif dan bercabang, sedangkan karang mati didominasi oleh karang mati yang telah ditumbuhi alga. Kedua kondisi tersebut menunjukkan bahwa terumbu karang membutuhkan upaya pemulihan untuk mengembalikan 
fungsi ekosistem yang terganggu sebagai akibat dari tingginya tingkat kerusakan karang.

\section{DAFTAR PUSTAKA}

1. Alamsyah, R., Uspar, Permatasari, A., \& Nurfadillah. (2019). Sebaran dan Luasan Terumbu Karang di Perairan Pulau Larearea Menggunakan Citra Landsat 8. Jurnal Agrominansia, 4(1), 49-54.

2. Arisandi, A., Tamam, B., \& Fauzan, A. (2018). Profil Terumbu Karang Pulau Kangea Kabupaten Sumenep Indonesia. Jurnal Ilmiah Perikanan Dan Kelautan, 10(1), 106-111.

3. Candri, D. A., Ahyadi, H., Riandinata, S. K., Virgota, A., \& Tenggara, N. (2019). Analisis Persentase Tutupan Terumbu Karang Gili Tangkong, Sekotong Kabupaten Lombok Barat. Jurnal Bio Wallacea, 5(1), 29-35.

4. Farid, M., Wahyu, P., \& Supriharyono. (2018). Perubahan Tutupan Terumbu Karang ditinjau dari Banyaknya Wisatawan di Tanjung Gelam Kepulauan Karimunjawa Menggunakan Citra Satelit Landsat 8 OLI. Journal of Maquares, 7(1), 18-27.

5. Hadi, T. A., Giyanto, Prayudha, B., Hafizt, M., Budiyanto, A., \& Suharsono. (2018). Status Terumbu Karang Indonesia 2018. Retrieved from http:/ /www.oseanografi.lipi.go.id

6. Kusumo, S., Adrianto, L., Boer, M., \& Suharsono. (2019). Indeks Resiliensi Terumbu Karang Dengan Pendekatan Sistem Sosial-Ekologi: Studi Kasus Kkpd Pulo Pasi Gusung, Selayar. Journal of Fisheries and Marine Research, 3(2), 110-118. https://doi.org/10.21776/ub.jfmr.2019.003.02.13

7. La Sara. (2014). Pengelolaan Wilayah Pesisir Gagasan Memelihara Aset Wilayah Pesisir dan Solusi Pembangunan Bangsa. Bandung: Penerbit Alfabeta.

8. Lutfhi, O. M., Akbar, D., Ramadhan, M. G., Rohman, M., \& Wahib, N. K. (2019). Studi Komparatif Tutupan Living dan Non Living Substrat Dasar Perairan Pulau Sempu Kabupaten Malang Menggunakan Metode Reef Check. Journal of Fisheries and Marine Research, 3(2), 1-8. https://doi.org/10.21776/ub.jfmr.2019.003.02.1

9. Madduppa, H., Subhan, B., Arafat, D., \& Zamani, N. P. (2017). Riset Dan Inovasi Terumbu Karang Dan Proses Pemilihan Teknik Rehabilitasi: Sebuah Usulan Menghadapi Gangguan Alami Dan Antropogenik Kasus Di Kepulauan Seribu. Risalah Kebijakan Pertanian Dan Lingkungan, 3(2), 130-139. https://doi.org/10.20957/jkebijakan.v3i2.15513

10. Manuputty, A. E. ., \& Djuwariah. (2009). Panduan Metode Point Intercept Transect (PIT) untuk Masyarakat. Jakarta: Coral Reef Rehabilitation and Management Program Lembaga Ilmpu Pengetahuan Indonesia. 
11. Menteri Negara Lingkungan Hidup. Keputusan Menteri negara Lingkungan Hidup Nomor 04 Tahun 2001 Tentang Kriteria Baku Kerusakan Terumbu Karang. , Pub. L. No. 04 Tahun 2001, 12 (2001).

12. Nurhidayat, I., Rustam, \& Rauf, A. (2019). Kondisi Terumbu Karang di Perairan Liukang Tangaya Kabupaten Pangkajene dan Kepulauan. Jurnal Pendidikan Teknologi Pertanian, 5(1), 41-48.

13. Suharsono. (2014). Biodiversitas Biota Laut Indonesia. Jakarta: Pusat Penelitian Oseanografi LIPI.

14. Suharyanto, \& Utojo. (2005). Kondisi Terumbu Karang di Pulau Sembilan Kabupaten Sinjai Sulawesi Selatan. Jurnal Biosfera, 22(3), 134-141.

15. Yusuf, M. (2013). Kondisi Terumbu Karang Dan Potensi Ikan Di Perairan Taman Nasional Karimunjawa, Kabupaten Jepara. Bulletin Oseanografi Marina, 2, 54-60.

16. Zamani, N. P. (2015). Kondisi Terumbu Karang dan Asosiasinya dengan Bintang Laut (Linckia laevigata) di Perairan Pulau Tunda, Kabupaten Seram, Provinsi Banten. Jurnal Teknologi Perikanan Dan Kelautan, 6(1), $1-10$.

17. Zewanto, I., Nasir, M., \& Kurnianda, V. (2017). Persentase Tutupan Karang di Pantai Ulee Kareung Kecamatan Simpang Mamplam Kabupaten Bireuen. Jurnal Ilmiah Mahasiswa Kelautan Dan Perikanan Unsyiah, 2(2), 302-309. 